\title{
A Study on The Application of Task-based Language Teaching in Oral English Teaching in Junior Middle School
}

\author{
Ling Xu \\ Taizhou University, Taizhou 317000, China \\ E-mail:987584544@qq.com
}

Abstract: Task-based language teaching is not only the teaching method required by the new curriculum standard, but also the mainstream teaching mode. It is designed on the basis of improving students' language application ability. Students are the center and teachers are in the leading position. The purpose is to complete the learning task. Usually, the task is completed in the form of group cooperation, so that students have a positive and active role in learning. The new curriculum standard puts forward clear requirements for junior middle school students' oral English level. Therefore, the application of task-based language teaching in oral English class will certainly help to improve the quality and efficiency of lectures. This paper will analyze the current situation of oral English Teaching in junior high school and put forward effective strategies. ${ }^{[1]}$

Keywords: Task-Based Language; English in Junior High School; Spoken Language; Communication

\section{Introduction}

Task based language learning (TBLT) is a learning theory put forward by foreign language teaching method researchers and second language acquisition researchers based on a lot of research and practice in the 1980s. TBLT is a new teaching mode, the core of which is "learning by doing" and "doing things with the language". ${ }^{[2]}$ The purpose of this teaching method is to cultivate students' ability to solve problems in English, so its advantages are obvious. First of all, TBLT requires students to cooperate in groups to complete various task activities, which can effectively stimulate students' interest in learning and improve their team cooperation ability. Secondly, in the process of completing tasks in class, the combination of language knowledge and skills helps to cultivate students' comprehensive application ability. Students not only learn knowledge, but also cultivate their ability of independent thinking and adaptability, which is conducive to the overall development of students. If the TBLT is combined with oral English Teaching in junior middle school, it can better face all students and play the leading role of teachers. Therefore, there is an inseparable relationship between the two. ${ }^{[3]}$

\section{Principles in task-based oral English teaching}

\subsection{Tasks should have clear objectives and reasonable forms}

In the TBLT, the teacher introduces the task topics, the students study purposefully under the driving of the task. And this task is to effectively combine various activities in life with students' own cognitive structure and learning experience. Therefore, teachers should be clear about the purpose of each task designed, at the same time, they should also consider the feasibility and practical feasibility of the task, follow the theory of the zone of proximal development as far as possible, and provide some slightly difficult contents on the basis of students' existing knowledge and ability, so that the students' ability level can be greatly improved after teaching.

\section{Copyright (C) 2020 Ling Xu}

doi: $10.18282 /$ le.v9i7.1474

This is an open-access article distributed under the terms of the Creative Commons Attribution Non-Commercial License

(http://creativecommons.org/licenses/by-nc/4.0/), which permits unrestricted non-commercial use, distribution, and reproduction in any medium, provided the original work is properly cited. 


\subsection{The oral task should be designed according to the level of middle school students}

The tasks should be set in line with the life experience, emotional experience and cognitive level of middle school students, and can arouse the resonance of students. This does not require that everything is completely true, but we should try to create some environment close to life, so that they can have something to say and something to say. The difficulty of the task has a gradient, from easy to difficult, layer by layer.

\subsection{The design of tasks should have results and reflection}

At the end of the task, teachers and students usually summarize the students' performance in the task, which can combine the students' self-evaluation, group evaluation and teacher evaluation. Through the evaluation, students can learn from each other, increase the opportunity of practice, and improve the oral expression ability. Finally, the teacher can summarize the situation of the students' completion of the task, and focusing on positive evaluation. The students will reflect on the minor problems and correct them in the continuous practice. ${ }^{[4]}$

\section{The present situation and application of tblt in oral English teaching in junior middle school}

For a long time, foreign language teaching in China has paid more attention to the accumulation of grammar knowledge and vocabulary, and largely ignored the teaching of oral English. In terms of listening, speaking, reading and writing, the ability of speaking is relatively weak. After learning English for several years, middle school students still find it difficult to communicate with others in English, because they don't practice much and are too shy to speak. At the same time, they don't have a good language environment. TBLT can effectively solve the problems in oral English teaching, and its implementation includes three aspects: ${ }^{[5]}$

\subsection{Pre-task}

Before the task, teachers need to clarify the theme, define the goal, and present the task through listening, speaking, reading, writing, reading and so on. This is the leading part, so that students' understanding and experience value before the task can be maximized and students' tension and discomfort can be alleviated to a certain extent so as to build selfconfidence.

\subsection{Task cycle}

This is the most core step. In this link, it should account for about $70 \%-80 \%$ of the teaching time. Students begin to learn new knowledge. Teachers design a number of small tasks to form a task ring. Students use communication to solve various problems. Teachers act as organizers and supervisors to help students complete the tasks. ${ }^{[6]}$

\subsection{Language focus ${ }^{[7]}$}

The first is analysis, that is, students evaluate the performance of other groups; the second is practice, in which students practice language difficulties under the guidance of teachers. The knowledge and skills learned by students through completing tasks are transformed into the ability to use English in life. Teachers point out areas for improvement, such as learning strategies, cooperative learning, etc., and encourage students to evaluate each other.

\section{Suggestions on the application of tblt in junior middle school oral English calss}

\subsection{Distinguish the difference between "task" and "practise"}

Task activities are not mechanical language training, but focus on the cultivation of students' ability and strategy to perform tasks, which need to be completed by teamwork, while exercises are usually completed by students independently. Only a real task can ensure students to carry out meaningful language output activities, can promote students to obtain, process and use information, and develop the ability to solve problems in English. Case: U5 Why do you like Pandas? (Pep Edition Junior Middle School English Grade 7 Volume 2)

Teaching objectives: 1. Be able to understand, speak and write "Why do you like Pandas?" “, "Because they're very cute." 
Be able to express the animals you like and why.

Design 1:Make sentences with "Why do you ......?" "Because ......"

Design 2:The school decides to go to the zoo next week, discuss with your group members what animals do you want to see. Each group should make a list about all the members' favorite animals. Please write complete sentences with "why do you......?" and "Because......",

In the above case, design 2 is a task but design 1 is a exercise without context, both of which focus on the results of the linguistic form.

\subsection{Arouse students' learning enthusiasm}

Junior middle school is also the main period to cultivate students' interest in learning English. Therefore, when designing tasks, teachers should design the task topics that students are interested in according to their age and psychological characteristics, and create a relaxed and natural learning environment, activate students' thinking and promote students' positive expression. Tasks are always formed in certain situations, which are the context in which oral communication activities can be carried out. Task-based oral English teaching requires teachers to design more realistic oral communication situations, introduce real corpus into the learning environment, and make the situation of classroom oral tasks closer to the reality of life. ${ }^{[9]}$

For instance, U2 from the eighth grade edition of PEP: how often do you exercise? Teachers can introduce the topic through "Do you like doing exercise?", so that students can freely discuss, exchange ideas, and activate the classroom atmosphere. Then, ask students how often, how to express the number of times in the answer sentence to the students in English, and replace "exercise" with"go to the movies", "shop", "watch TV" and other activities.

\subsection{Strengthen the training of practical spoken English}

Encourage students to talk in English, and give more topics related to real life in the training, such as "talk about your families". Let the students output independently, and then let the teachers comment on it, or let the students evaluate each other. The following are classroom cases for grade one students:

\begin{tabular}{|l|l|}
\hline $\begin{array}{l}\text { Subject Content } \\
\text { Sentence Structure }\end{array}$ & $\begin{array}{c}\text { Family members } \\
\text { My mother is a } \ldots \\
\text { Her hobby is....... }\end{array}$ \\
\hline $\begin{array}{l}\text { Task Recommendations } \\
\text { Task Results }\end{array}$ & $\begin{array}{l}\text { Students are required to prepare the photos of their families in } \\
\text { advance. In groups of 3-4 students, introduce the situation of their } \\
\text { families, such as: occupation, hobbies, etc. }\end{array}$ \\
\hline Task Evaluation & $\begin{array}{l}\text { Each group selects 1-2 students to show the results, and the } \\
\text { teacher comments on the results. }\end{array}$ \\
\hline
\end{tabular}

This task comes from students' life. Students have a wide range of participation and a large amount of activities. They can flexibly move various words and phrases. It is beneficial to cultivate students' diffusion thinking and stimulate their interest in learning. ${ }^{[10]}$

\section{Conclusion}

The combination of TBLT and oral English teaching is a feasible teaching method. Teachers' implementation of TBLT in junior middle school English classes can not only improve the classroom teaching efficiency, but also improve students' oral English expression ability. English teachers should further explore and strengthen the use of TBLT so as to give full play to its teaching value, improve the quality of junior middle school English teaching and improve students' oral English ability. 


\section{References}

1. Nunan,D.Task-based Language Teaching[M].Cambridge University Press,2004

2. Willis, j. A Framework for task-based learning[M].London:Longman1996.

3. Chen Donghua. Primary School English Teaching Design [M]. Higher Education Press, 2015

4. Huang Zhiqiang. The role of TBLT in Oral English Teaching [J]. Exam Weekly, 2008-20

5. Lu Zhe. Using task-based teaching method to get out of the predicament of English Grammar church [J]. Gansu Science and Technology Review, 2005, (6).

6. Li Xiaoxia. Research on the Use of task-based teaching Mode to improve the Oral English ability of junior middle School students [D].Shanghai Normal University, 2012

7. Stan. Research on the Application of Task-based Language Teaching in oral English teaching of junior middle School [J].Science and Technology Vision, 2014-24

8. Wang Qiang. English Teaching Method Design [M]. Higher Education Press, 2007-5

9. Wang Aihua. Research on the Application of TBLT in Oral English Teaching in Junior Middle School [J].Teaching Research, 2014-12

10. Zhang Jinghan.Application of TBLT in College Oral English Teaching [J]. Curriculum Education Research (New Teacher Teaching), 2015-19 